\title{
How the Level of Economic Growth and the Constituent Elements of Innovation Attract International Talent?
}

\author{
Maria Jose Miranda-Martel ${ }^{1}$, Antonio Mihi-Ramirez ${ }^{2}$, Jesus Arteaga-Ortiz ${ }^{3}$ \\ ${ }^{1,3}$ University of Las Palmas de Gran Canaria \\ Campus de Tafira \\ Edificio Departamental de Empresariales 35017 \\ Las Palmas de Gran Canaria (Spain) \\ E-mail.mariajose.miranda@ulpgc.es; jesus.arteaga@ulpgc.es \\ ${ }^{2}$ Granada University \\ Campus Cartuja, 18071, Granada (Spain) \\ E-mail.amihi@ugr.es \\ cross $^{\text {ref }} \underline{\text { http://dx.doi.org/10.5755/j01.ee.28.2.17518 }}$
}

\begin{abstract}
The international flow of highly skilled workers has a large effect on any country. Simultaneously, innovation and its constituent elements allow increasing growth in a sustainable way. This paper analyses the impact of the most important constituent elements of innovation found in literature on immigration of highly skilled workers. In order to do that, we performed a cluster analysis of 182 countries (OECD and non-OECD members), which are net exporters of highly skilled immigrants, and 25 receiving countries members of the OECD. It includes a detailed discussion of results by world regions including examples of specific programmes and policies for each variable of the study. Overall, our results confirm that the attraction of international talent is related to both the constituent elements of innovation and the level of economic growth. In this regard, countries like the U.S., Australia, Canada and the United Kingdom are among the main destinations of highly skilled immigrants of any region of origin due to the implementation of policies that favor the development of innovation. However, access restrictions for highly skilled workers would limit the effects of those policies. Therefore, in the design of strategies for attracting talent, the qualification of such workers should take precedence over their country of origin, thus encouraging greater innovation activities among those highly skilled immigrants.
\end{abstract}

Keywords: High Skilled Migration, Innovation, Patents, GERD, Scientific Journals, Graduate Enrolment Ratio, Economic Growth.

\section{Introduction}

At a time when society is aging and the knowledge economy rules, countries and companies need highly skilled immigrants (HSI) even in times of economic crisis (GarciaRodriguez et al., 2015). Hence the application of protectionist measures affecting the flow of HSI not only makes no sense, but could slow economic recovery (Benassy \& Brezis, 2013).

Most skilled workers are considered very important for any country given their impact on economics development, and any change in their number or composition is examined very carefully, especially in the case of migration (Metelski \& Mihi-Ramirez, 2015; Beine et al., 2011; Krisciunas \& Greblikaite, 2007).

Moreover, although economically there are several factors that determine the level of development of an economy, most of them tend to have diminishing returns in the long term. Innovation activities, on the other side, allow a level of higher productivity growth and the longer such activities are executed, the greater the effect (World Economic Forum, 2014).

Innovation and its constituent elements have a major impact on the migration flows of highly skilled workers (Mihi-Ramirez et al., 2016; Bosetti et al., 2015; Zheng \& Ejermo, 2015; Masuduzzaman, 2014). In particular, a greater degree of innovation in a country and greater economic growth could boost the arrival of HSI, which is the general hypothesis of this research.

HSI should be considered by countries and companies as a source of resources and strengths which, together with other factors of innovation, make possible sustainable present and future growth. It is especially important in times of recession and global competition like we are currently experiencing (Mihi-Ramirez et al., 2016; Bosetti et al., 2015; Naghavi \& Strozzi, 2015; OECD, 2015; Abdelbaki, 2009; Jaffe et al., 1993). This fact requires studies on the international level in order to understand the global changes that are happening (Arslan et al., 2014).

Given the above, the primary aim of this research is to analyze the impact of the most significant components of innovation addressed in literature on immigration of highly skilled workers: 1) number of patents, 2) spending on R\&D as a percentage of GDP, GERD), 3) number of articles in scientific and technical journals, 4) enrolment in graduate studies. We also examine economic growth (measured by GDP per capita).

In order to achieve this goal, we used cluster analysis, which allowed us to specify the relationship between the studied countries and establish a hierarchy in the variables analyzed; this was essential in the case of international samples (Aldenderfer \& Blashfield, 1984). 
In the literature about migration, international empirical analyses are scarce since such studies are generally carried out at a regional or national level (Hussain, 2015; Beine et al., 2011). Since international migration has changed rapidly in recent decades, especially in the case of skilled migration, international comparisons are crucial (Metelski \& MihiRamirez, 2015; Arslan et al., 2014.). This paper analyzed a sample of 207 countries: 182 sending countries of highly skilled immigrants and 25 OECD' countries receiving those immigrants. The paper is divided into five sections:

1) Introduction,

2) Theoretical overview,

3) Methodology and Empirical analysis,

4) Discussion of results, and

5) Conclusions.

Following this introduction, section 2 establishes the theoretical framework by analyzing current migration theories and the various contributions made in terms of skilled migration analysis. This section also studies innovation and its constituent elements and the relationships between highly skilled immigration, innovation and economic growth. Section 3 explains the choice of the sample while also clarifying the variables and methodology used in the analysis. Section 4 discusses the results of the empirical analysis. Finally, section 5 includes the main conclusions of the research paper, explain the primary limitations of the research and propose new avenues for future research.

\section{Immigration of Highly Skilled Personnel, Innovation and Economic Growth}

\section{Highly Skilled Migration in Migration Theories}

The most accepted view about the origins of highly skilled migration indicates the existence of a number of pushpull factors that encourage people to move from one country to another, meaning that migration is simply the result of an economic balance mechanism between countries exporters of highly skilled migrants (least developed) and receiving countries (more developed) (Kerr, 2010). In this sense, Hunt \& Gauthier-Loiselle (2010) noted that receiving workers, researchers and qualified students is very beneficial from an economic point of view for the host country, but this depends on the motivations of these immigrants, which are based on an assessment of costs and benefits.

According to the global systems theory, international movements are not just the result of underdevelopment, but are also the effect of previous historical factors on asymmetric economic and political contacts between exporting and receiving countries (Ports \& Walton. 1981).

In the 1990s, the Theory of Human Capital, originally introduced in 1964 by G. Stanley Becker, gained new currency. In the new version of this theory regarding skilled migration, Becker suggests that immigrants with advanced education (Ph.D.) and with some work experience could have similar labor opportunities as local people in the same labor market, regardless of race, ethnicity or gender (Becker, 2009).

One of the main trends in the scientific literature on highly skilled migration is the Endogenous Growth theory and the benefits of "brain gain". The main research on this trend cites Vidal (1998), who established as a general hypothesis that the migration of skilled workers encourages others to acquire a better education by offering them the opportunity to migrate elsewhere for positions commensurate with their education level.

Moed \& Halevi (2014) noted that countries exporters of highly skilled migrants could exploit knowledge resources generated abroad through ethnic networks established between groups of highly skilled immigrants in the receiving country. These networks would act as a receptacle of knowledge and innovation, comprising highly skilled immigrants in the receiving country that have some characteristics in common: same area of expertise, working in the same research centre, shared culture, and could also act as a factor of attraction for additional highly skilled immigrants in the future. In this sense, the development of primarily local knowledge capital could help in the creation of new innovation nodes that could reverse the initial migratory process.

\section{Innovation and its Constituent Elements}

Although the acquisition of existing technologies or improvements of such acquired technologies allows for large productivity gains in less developed countries, this is not the case in highly developed countries, which need to create more advanced products and processes in order to maintain their competitive advantage and achieve a greater value added. Specifically, this means adequate investment in research and development (R\&D), and resisting pressures to cut spending on $R \& D$, which is critical for sustainable growth in the future. This would result in a significant amount of newly created knowledge and the availability of skilled staff necessary for excellence scientific research. Such research would generate the knowledge needed to build new technologies, expand collaboration in research, and advance technological development (World Economic Forum, 2014; Sara et al., 2012; Fan, 2011; Love \& Roper, 1999). Protecting innovations through patents is essential so that companies can obtain benefits that allow continued investment in innovation activities (Schumpeter, 1934; Eurostat and OECD, 2005).

Another main constituent element of innovation is the dissemination of all novel and recent knowledge and technologies (Eurostat and OECD, 2005; Schumpeter, 1934;), accounting for the number of articles published in scientific journals (Mihi-Ramirez et al., 2016; Stephan \& Levin, 2001).

Relationship between Highly Qualified Immigrants, Innovation and Economic Growth.

Patents and data on citations are constituent elements of innovation very useful to assess and share technological changes (Mihi-Ramirez et al., 2016; Jaffe \& Trajtenberg, 2002). Abdelbaki (2009) showed the relationship between increased presence of foreign graduates and growth in patent production. These percentages established the role of scientific production as an incentive factor in talent drain from countries with developing economies.

In this sense, Hunt \& Gauthier-Loiselle (2010) and Kerr (2010) demonstrated that a higher number of skilled immigrants increase the number of patents in United States in long term. Also Bosetti et al. (2015) found similar results in the case of Europe.

Naghavi \& Strozzi (2015) showed that migration is related to the patents and innovative potential of the country by increasing the absorptive capacity of the sending country. 
In addition, several studies address the connection between the rate of expenditure on R\&D as a percentage of GDP and the number of HSI received.

Cekanavicius \& Kasnauskiene (2009) pointed up that investment in R\&D attract HSI. From another perspective, Gagliardi (2011) showed that the higher expenditure in R\&D the higher HSI.

Benassy \& Brezis (2013) proposed econometric growth models based on the interaction between technology applications and government policies, where they found that skilled immigration depends partly on GDP and, in particular, spending on R\&D as a percentage of that GDP.

Arslan et al. (2014) presented a report to the OECD on the characteristics of migration in light of the economic crises and changes that happened in the world economy between 2000 and 2010. Two aspects that were highlighted in the report were that the "brain drain" is greater in countries with low or medium-low level of incomes; and that the growth of highly skilled migrants in that time period varies greatly among receiving countries.

As for the production of articles published in scientific and technical journals and HSI, the OECD territorial report on Canada (OECD, 2009) documented that growth in the share of production of patents and scientific papers by people of foreign origin and the scientific production of natives are related. Thus, from a sample of U.S. metropolitan regions between 1975-2004, an increase of $1 \%$ in the share of patents by HSI correlated by $0.6 \%$ of overall scientific production, measured in terms of the patent applications and related scientific publications. The coefficient is high in the sense that the share of invention by immigrants during the period was $20 \%$ (Kerr, 2008).

Moreover, based on the findings of the aforementioned study, Hunt \& Gauthier-Loiselle (2010) chose assessing HSI in the U.S. in terms of production of patents and citations of scientific papers in journals as the aim of their research. Among the conclusions of their paper, and in line with the work of Stuen et al. (2007) and Kerr (2008), it was established that immigrant scientists and engineers with graduate degrees are more attracted by greater amount of knowledge created, i.e. patents and publications.

Moreover, the analysis of the number of enrolments in tertiary studies is perhaps one of the aspects that most directly correlates the migration of intellectual capital to innovation (Dumont et al., 2007), and yet is one of the lesser discussed elements in the scientific literature on the subject. The importance of this indicator in scientific literature is seen in research papers such as the one by Gungör \& Tansel (2007), which addressed the issue of the change of habits among postgraduate and Ph.D. students in Turkey, who, increasingly, sought to complete their education abroad for the facilities and rewards that it entailed, having as a result the increase of permanent migrants who later decided not to return.

In another study, Hunt \& Gauthier-Loiselle (2010) analyzed the relationship between skilled immigration and innovation from different points of view. They analyzed not only its influence on the increase of economic productivity, GDP and R\&D, but also established how skilled immigration enrolled in postgraduate studies favors the production of scientific articles in receiving countries and other relevant additional consequences. For its part, the Hopkins \& Levy (2012) paper on the enrolment of students in third cycle studies determined that this factor increases the degree of HSI. It is a report prepared for the Big Innovation Centre in the UK, where data from various institutions such as the OECD are collected aiming to study the effects on the economy and innovation by the arrival of HSI to the UK.

Regarding the importance of analyzing the GDP per capita when studying migration, the authors Balaz et al. (2004) argued that the migration of such people produces a significant change in the GDP of the country that loses these HSI, and the one that receives them. We also find GDP as the core data of the research paper by Jajri \& Ismail (2014), which analyzed the determining factors that trigger migration originating in the ASEAN-3 countries towards Malaysia. According to these authors the reasons that this flow occurs are related exclusively to the gross domestic product of the analyzed countries (Indonesia, Thailand, Philippines and Malaysia).

Dreher \& Poutvaara (2006) and Nguyen et al. (2015) noted that there is consensus on the fact that higher living standards, employment rate or the level of GDP growth are variables that encourage highly skilled emigration. Niebuhr (2006) also found that GDP is an attraction factor for foreign labor talent when he analyzed a sample of immigrants in Germany. In another study, Benassy \& Brezis (2013) analyzed the interaction between the application of technology and government policies. Their results indicate that skilled immigration depends on the size of GDP.

\section{Methodology}

In order to analyze the impact of the most important constituent elements of innovation according to the literature on immigration of highly skilled workers, we had to contrast and compare the theoretical relationships explained previously regarding the relationship between the number of HSI and various factors related to innovation, such as number of patents, spending on R\&D as a percentage of GDP, GERD, number of articles in scientific and technical journals, enrolment in Ph.D. studies, and GDP per capita as a growth indicator.

According to the research objective we performed an analysis of 207 countries - 182 source countries of highly qualified immigrants (OECD and non-OECD members), and 25 recipient countries (members of the OECD) who receive this type of immigrants from six global regions: Africa, Asia, Europe, North America, Central and South America and Oceania.

Data on HSI, were obtained from the OECD (2011) "Database on Immigrants in OECD and non-OECD Countries, DIOC database", prepared by OECD in collaboration with the World Bank and the International Migration Institute at Oxford University. This database includes migration data on different categories (education, age, employment status) for a sample of OECD and nonOECD countries. In our research, we particularly used data on emigration rates of people with higher qualifications in 2011, meaning, those found in International Standard Classification of education, ISCED. ISCED levels 5-6 as defined by UNESCO. This is the latest data on HSI migration flows worldwide, and it is provided adjusted taking into account differences in migration record-keeping in different countries, allowing for international comparisons (de Beer et 
al., 2010). The receiving countries that were selected are those OECD countries that according to the database receive the largest number of immigrants from the countries of origin. As for the sample selection for countries of origin (exporters of HSI), it includes all the countries in the database.

Regarding data on patent applications by foreigners in receiving countries, it was obtained from the OECD patent database (OECD, 2011), which includes international patent applications submitted through the procedure agreed on in the Patent Cooperation Treaty or by a national patent office for the protection of exclusive rights on an invention: a product or process that offers a new way of doing something or a new technical solution to a problem, which grants protection of the invention to the patent holder for a period of usually 20 years (OECD, 2011).

Data on the spending of host countries on $R \& D$ as a percentage of their GDP (GERD) was also obtained from the OECD (2011), which obtained the data based on information collected by the United Nations on the areas of education, science and culture, and which includes ordinary and capital spending on R\&D (both public and private) in the creative work undertaken systematically to increase knowledge, including knowledge of humanity, culture and society, and the use of knowledge for new applications. This R\&D spending includes basic research, applied research and experimental development spending (OECD, 2011).

Information on articles in scientific and technical journals means the number of scientific and engineering articles published in receiving countries in the following fields: physics, biology, chemistry, mathematics, clinical medicine, biomedical research, engineering and technology and earth sciences and space. The OECD (2011) and the World Bank referenced this data based on information obtained from the National Science Foundation Science and Engineering Indicators. Data on the enrolment rate in third cycle studies in receiving countries was obtained from the OECD (2011) database on education which includes the percentage of foreign enrolment of graduate studies (students of master's degrees, doctorates and general postgraduate studies) in relation to total enrolments in those same receiving countries.

Finally, the data on the GDP per capita of receiving countries was obtained from the OECD's database of economic indicators, and refers to the monetary market value of all final goods and services produced in a country during a year in proportion the population and taking into account inflation (OECD, 2011). All the data that was obtained from the aforementioned international institutions has been processed by them in order to enable international comparisons.

We used cluster analysis, a statistical method that allows establishing a hierarchy of variables according to their importance in distributing countries into groups. This allows detailing the relationship between the countries being studied according to their scores on all variables, which is essential in order to apply for samples with many records, as is the sample we work with which includes more than 180 countries (Aldenderfer \& Blashfield, 1984).

The latter task provides a photograph of the latent structure of the sample, as it can be divided into sets consisting of countries with similar scores. This allows determining which variables are more discriminating regarding the target group, meaning what variables best characterize or define countries when dividing them into sets (Bayley, 1994).

According to this technique we followed the Two Steps and k-Means procedures, which were used in order to compare their solutions (Aldenderfer \& Blashfield, 1984; Bayley, 1994). The two-step procedure, or bi-stage sampling, provides information on the composition of the clusters obtained and the influence of the different variables used for generating those clusters (SPSS Technical Report: The SPSS Two Step Cluster Component, 2001). The second of the two procedures used in the cluster analysis (k-Means) provides a series of tables ANOVA in which we can test the relevance of the different variables for group creation through the F test, or F distribution (Everitt, 1993).

Six cluster analyses were performed in order to include the data on the six HSI originating regions. By repeating the calculations for the two procedures (Two Phase and k-Means) we got 12 results. The entered data are differentiated by the value of HSI (for Africa, Asia, Europe, North America, South and Central America and Oceania). Hence, both the number of resulting groups (clusters), and their composition, or the grouping powers of the variables, will not change significantly in the results, due to the fact that the differences being observed are a direct consequence of the influence of the HSI variable. However, we can get an idea about what variables help us most to classify our sample into groups and, therefore, know what variables are most influential regarding receiving countries.

\section{Results by Area of Origin: Africa}

In the cluster analysis, we seek to identify the variables that best serve to group the sample, meaning, the classification power of the variables. The result with five clusters more equitably distributed the countries in the sample. The variable "Number of patents" is by far the most important when dividing the sample into five groups. It is followed in importance by the number of scientific articles. Thus, the variable "Number of scientific articles" has about $65-70 \%$ of the grouping power of the "Number of patents" variable. The variable "Number of immigrants from Africa" was analyzed based on other variables, therefore, in accord with the research objective, we will focus on explaining the behaviour of the other five the variables.

The two solutions that contribute most relevant variables are the ones of clusters three and four. The ANOVA Table 1 shows their relevance or grouping power. The group with four clusters has a larger number of receiving countries, where the U.S. forms the fourth cluster, Australia, Canada, UK, Italy, the Netherlands and Spain form the third, Luxembourg and Norway, the second, and the other countries, the first cluster. We have the following predictors and F parameters, where the latter indicates the importance, or grouping power, of the first:

- Patents, F (3.21) = 518.6, p <0.001

- Scientific articles, F (3.21) = 416.95, p <0.001

- GDP, F (3.21) = 13.46, p <0.001

- "Third cycle ed.", F (3.21) = 3.20, p = $0.04<0.05$

The "Number of patents" variable is the most important, followed by the number of publications, economic growth measured by GDP, and rate of enrolment in third cycle studies. The definition of the four clusters are in Table 2. 
Table 1

ANOVA. Africa

\begin{tabular}{|c|c|c|c|c|c|c|}
\hline & \multicolumn{2}{|l|}{ Cluster } & \multicolumn{2}{|l|}{ Error } & \multirow{2}{*}{$\mathrm{F}$} & \multirow{2}{*}{ Sig. } \\
\hline & Root mean square (RMS) & df & Root mean square (RMS) & df & & \\
\hline Third cycle education enrolment ratio (\%) & 631.016 & 3 & 196.97 & 21 & 3.20 & .044 \\
\hline Patent applications by non-residents & 23066435491.30 & 3 & 44477805.80 & 21 & 518.60 & .00 \\
\hline Research and development spending (\% of GDP) & .51 & 3 & .89 & 21 & .57 & .63 \\
\hline Articles in scientific and technical journals & 13440757373.03 & 3 & 32235558.01 & 21 & 416.95 & .00 \\
\hline GDP per capita (ppp \$ 2005) & 1240430545.32 & 3 & 92109388.95 & 21 & 13.467 & .00 \\
\hline AFRICA & 315861380.75 & 3 & 6848941.70 & 21 & 46.11 & .00 \\
\hline
\end{tabular}

Table 2

Averages of the Final Clusters. Africa

\begin{tabular}{|c|c|c|c|c|}
\hline & Cluster 1 & Cluster 2 & Cluster 3 & Cluster 4 \\
\hline Third cycle education enrolment ratio (\%) & 73.17 & 46.15 & 74.56 & 94.27 \\
\hline Patent applications by non-residents & 1067 & 304 & 10301 & 271033 \\
\hline Research and development spending (\% of GDP) & 2.10 & 1.53 & 1.76 & 2.76 \\
\hline Articles in scientific and technical journals & 4181 & 2491 & 26762 & 208600 \\
\hline GDP per capita (ppp \$ 2005) & 29744.61 & 73981.43 & 37737.43 & 49853.68 \\
\hline AFRICA & 533 & 235 & 5380 & 31305 \\
\hline
\end{tabular}

\section{Results for Asia}

As in the previous case, the results for clusters three and four showed four significant variables in addition to the variable "Number of immigrants", and of those, we chose the four cluster results because they have more groups of countries than the three cluster result. The relevance of the variables is collected in the ANOVA Table 3.

- Patents, F (3.21) = 1378.73, p <0.001

- Scientific articles, $F(3.21)=215.54, \mathrm{p}<0.001$

- GDP, F (3.21) = 12.85, $\mathrm{p}<0.001$

• "Third cycle ed.", F (3.21) = 3.18, p =.04<.05

In the case of Asia, the "Number of patents" variable is the most important followed by the "Number of publications", economic growth measured by GDP and the rate of enrolment in third cycle studies (Table 3). For Asia, these groups are composed of: cluster one, U.S.; cluster two, Luxembourg and Norway; cluster three, Australia, Canada and the UK; and cluster four, other countries (Table 4).

Table 3

ANOVA. Asia

\begin{tabular}{|c|c|c|c|c|c|c|}
\hline & \multicolumn{2}{|l|}{ Cluster } & \multicolumn{2}{|l|}{ Error } & \multirow{2}{*}{$\mathrm{F}$} & \multirow{2}{*}{ Sig } \\
\hline & Root Mean Square (RMS) & df & Root Mean Square (RMS) & df & & \\
\hline Third cycle education enrolment ratio (\%) & 628.93 & 3 & 197.26 & 21 & 3.18 & .045 \\
\hline Patent applications by non-residents & 23259687669.91 & 3 & 16870351.72 & 21 & 1378.73 & .00 \\
\hline Research and development spending (\% of GDP) & .34 & 3 & .91 & 21 & .372 & .77 \\
\hline Articles in scientific and technical journals & 13236535121.47 & 3 & 61410165.37 & 21 & 215.54 & .00 \\
\hline GDP per capita (ppp \$ 2005) & 1220499454.08 & 3 & 94956687.70 & 21 & 12.85 & .00 \\
\hline ASIA & 36360418859.2 & 3 & 10323240.42 & 21 & 3522.19 & .00 \\
\hline
\end{tabular}

Table 4

Averages of the Final Clusters. Asia

\begin{tabular}{|c|c|c|c|c|}
\hline & \multicolumn{4}{|c|}{ Cluster } \\
\hline & 1 & 2 & 3 & 4 \\
\hline Third cycle education enrolment ratio (\%) & 94.27 & 46.15 & 74.34 & 73.43 \\
\hline Patent applications by non-residents & 271033 & 304 & 20139 & 972 \\
\hline $\begin{array}{l}\text { Research and development spending (\% of } \\
\text { GDP) }\end{array}$ & 2.76 & 1.53 & 1.98 & 2.01 \\
\hline Articles in scientific and technical journals & 208600 & 2491 & 31884 & 6938 \\
\hline GDP per capita (ppp \$2005) & 49853.68 & 73981.43 & 39864.20 & 30670.83 \\
\hline ASIA & 338313 & 797 & 29174 & 963 \\
\hline
\end{tabular}

\section{Results for Europe}

The results with better quality solutions are the ones with, respectively, five and two clusters. Among the results with either five or two clusters, we once again opted for the solution with five clusters which provides a greater degree of clustering and distribution. Cluster analysis, besides the variable "Number of patents", also gives importance to the variable "Scientific production".

In this analysis, the best solutions are the ones with three and four groups, because with them we reach five variables that contribute significantly to the distribution of countries in these groups. Solution four has the most balanced groups.
The relevance of those variables is collected in the ANOVA Table 5.

The receiving countries where the aforementioned variables are most relevant in the case of Europe (Table 6) are: cluster one, Other countries; cluster two, Luxemburg and Norway; cluster three, Australia, Canada, UK; and cluster four, U.S. 
Table 5

ANOVA. Europe

\begin{tabular}{|c|c|c|c|c|c|c|}
\hline & \multicolumn{2}{|l|}{ Cluster } & \multicolumn{2}{|l|}{ Error } & \multirow{2}{*}{$\mathrm{F}$} & \multirow{2}{*}{$\begin{array}{c}\text { Sig } \\
\text {. }\end{array}$} \\
\hline & Root Mean Square (RMS) & df & Root Mean Square (RMS) & df & & \\
\hline Third cycle education enrolment ratio (\%) & 646.402 & 3 & 194.77 & 21 & 3.319 & .04 \\
\hline Patent applications by non-residents & 23160594575.53 & 3 & 31026508.06 & 21 & 746.47 & .00 \\
\hline Research and development spending (\% of GDP) & .400 & 3 & .91 & 21 & .44 & .72 \\
\hline Articles in scientific and technical journals & 13306160730.55 & 3 & 51463649.79 & 21 & 258.55 & .00 \\
\hline GDP per capita (ppp \$2005) & 1203598477.98 & 3 & 97371112.86 & 21 & 12.36 & .00 \\
\hline EUROPE & 8530908478.62 & 3 & 22980574.13 & 21 & 371.22 & .00 \\
\hline
\end{tabular}

Table 6

Averages of the Final Clusters. Europe

\begin{tabular}{|c|c|c|c|c|}
\hline & Cluster 1 & Cluster 2 & Cluster 3 & Cluster 4 \\
\hline Third cycle education enrolment ratio (\%) & 72.81 & 46.15 & 76.89 & 94.27 \\
\hline Patent applications by non-residents & 1014 & 304 & 15156 & 271033 \\
\hline Research and development spending (\% of GDP) & 2.05 & 1.53 & 1.82 & 2.76 \\
\hline Articles in scientific and technical journals & 6051 & 2491 & 29641 & 208600 \\
\hline GDP per capita (ppp \$ 2005) & 30620.72 & 73981.43 & 37791.32 & 49853.68 \\
\hline EUROPE & 3833 & 3784 & 24174 & 166033 \\
\hline
\end{tabular}

\section{Results for North America}

The results with better quality solutions are the ones with, respectively, five and two clusters. Among the results with either five or two clusters, we once again opted for the solution with five clusters which provides a greater degree of clustering and distribution. Cluster analysis, besides the variable "Number of patents", also gives importance to the variable "Scientific production".

In this analysis, the best solutions are the ones with three and four groups, because with them we reach five variables that contribute significantly to the distribution of countries in these groups. Solution four has the most balanced groups. The relevance of those variables is collected in the ANOVA Table 7. The cluster distribution is very similar to the ones seen in previous paragraphs (Table 8): cluster one, Other countries; cluster two, Norway and Luxemburg; cluster three, U.S.; and cluster four, UK, Spain, Netherlands, Italy, Canada and Australia.

ANOVA. North America

\begin{tabular}{|c|c|c|c|c|c|c|}
\hline & \multicolumn{2}{|l|}{ Cluster } & \multicolumn{2}{|l|}{$\begin{array}{l}\text { Error } \\
\end{array}$} & \multirow{2}{*}{$\mathrm{F}$} & \multirow{2}{*}{ Sig. } \\
\hline & Root Mean Square (RMS) & $\mathrm{df}$ & Root Mean Square (RMS) & $\mathrm{df}$ & & \\
\hline Third cycle education enrolment ratio $(\%)$ & 631.01 & 3 & 196.97 & 21 & 3.20 & .044 \\
\hline Patent applications by non-residents & 23066435491.30 & 3 & 44477805.80 & 21 & 518.60 & .00 \\
\hline Research and development spending (\% of GDP) & .517 & 3 & .894 & 21 & .57 & .63 \\
\hline Articles in scientific and technical journals & 13440757373.03 & 3 & 32235558.01 & 21 & 416.95 & .00 \\
\hline GDP per capita (ppp \$ 2005) & 1240430545.32 & 3 & 92109388.95 & 21 & 13.46 & .00 \\
\hline NORTH AMERICA & 235082948.65 & 3 & 4486049.06 & 21 & 52.40 & .000 \\
\hline
\end{tabular}

\section{Results for Central and South America}

The results with better quality solutions are the ones with respectively four and five clusters. Among the results, we once again opted for the solution with five clusters which provides a greater degree of clustering and distribution.

Cluster analysis for the zone of Central and South America, besides the variable "Number of patents", also gives importance to the variable "Scientific articles".

In this analysis, the best solutions are the ones with three and four groups. The solution with four groups is again the most balanced one. The relevance of those variables is collected in the ANOVA Table 9. The cluster distribution (Table 10): cluster one, Other countries; cluster two, Norway and Luxemburg; cluster three, U.S.; and cluster four, UK, Spain, Netherlands, Italy, Canada and Australia.

\section{Results for Oceania}

In the case of Oceania, the most relevant variable that best helps distribute the countries of the sample into groups is "Number of patents" followed by "Scientific articles".

Once again, the best solutions provide up to five significant variables. They are those corresponding to three and four clusters. Of these, the one with four groups has distributed the countries in one group with 16 countries and three groups respectively with two, one and six countries. On the other hand, the solution of three clusters distributes countries in three groups with respectively 22 , one and two countries. Therefore, we chose the solution with four groups. The relevance of the variables is collected in the ANOVA Table 11.

The cluster distribution is very similar to the ones seen in previous paragraphs (Table 12): cluster one, Other countries; cluster two, Norway and Luxemburg; cluster three, U.S.; and cluster four, UK, Spain, Netherlands, Italy, Canada and Australia. 
Table 8

Averages of the Final Clusters. North America

\begin{tabular}{l|c|c|c}
\hline & Cluster 1 & Cluster 2 & Cluster 3 \\
\hline Third cycle education enrolment ratio (\%) & 73.17 & 46.15 & 94.27 \\
\hline Patent applications by non-residents & 1067 & 304 & 271033 \\
\hline Research and development spending (\% of GDP) & 2.10 & 1.53 & 2.76 \\
\hline Articles in scientific and technical journals & 4181 & 2491 & 10301 \\
\hline GDP per capita (ppp \$ 2005) & 29744.61 & 73981.43 & 208600 \\
\hline NORTH AMERICA & 427 & 314 & 49853.68 \\
\hline
\end{tabular}

Table 9

ANOVA. Central and South America

\begin{tabular}{|c|c|c|c|c|c|c|}
\hline & \multicolumn{2}{|l|}{ Cluster } & \multicolumn{2}{|l|}{ Error } & \multirow{2}{*}{$\mathrm{F}$} & \multirow{2}{*}{ Sig } \\
\hline & Root Mean Square (RMS) & $\mathrm{df}$ & Root Mean Square (RMS) & $\mathrm{df}$ & & \\
\hline Third cycle education enrolment ratio (\%) & 631.01 & 3 & 196.97 & 21 & 3.20 & .04 \\
\hline Patent applications by non-residents & 23066435491.30 & 3 & 44477805.80 & 21 & 518.60 & .00 \\
\hline Research and development spending (\% of GDP) & .51 & 3 & .89 & 21 & .57 & .63 \\
\hline Articles in scientific and technical journals & 13440757373.03 & 3 & 32235558.013 & 21 & 416.95 & .00 \\
\hline GDP per capita (ppp \$2005) & 1240430545.32 & 3 & 92109388.95 & 21 & 13,46 & .00 \\
\hline SOUTH \& CENTRAL AMERICA & 1888879677.63 & 3 & 6617822.14 & 21 & 285.42 & .00 \\
\hline
\end{tabular}

Averages of the Final Clusters. Central and South America

Table 10

\begin{tabular}{|c|c|c|c|c|}
\hline & Cluster 1 & Cluster 2 & Cluster 3 & Cluster 4 \\
\hline Third cycle education enrolment ratio (\%) & 73.17 & 46.15 & 94.27 & 74.56 \\
\hline Patent applications by non-residents & 1067 & 304 & 271033 & 10301 \\
\hline Research and development spending (\% of GDP) & 2.10 & 1.53 & 2.76 & 1.76 \\
\hline Articles in scientific and technical journals & 4181 & 2491 & 208600 & 26762 \\
\hline GDP per capita (ppp \$ 2005) & 29744.61 & 73981.43 & 49853.68 & 37737.43 \\
\hline SOUTH \& CENTRAL AMERICA & 194 & 146 & 77527 & 4482 \\
\hline
\end{tabular}

\section{ANOVA. Oceania}

Table 11

\begin{tabular}{|c|c|c|c|c|c|c|}
\hline & \multicolumn{2}{|l|}{ Cluster } & \multicolumn{2}{|l|}{ Error } & \multirow[b]{2}{*}{$\mathrm{F}$} & \multirow{2}{*}{ Sig } \\
\hline & Root Mean Square (RMS) & df & $\begin{array}{lll}\begin{array}{l}\text { Root } \\
\text { (RMS) }\end{array} & \text { Mean } & \text { Square } \\
\end{array}$ & df & & \\
\hline Patent applications by non-residents & 23066435491.30 & 3 & 44477805.80 & 21 & 518.60 & .00 \\
\hline Research and development spending (\% of GDP) & .51 & 3 & .894 & 21 & .579 & $\begin{array}{c}.63 \\
5\end{array}$ \\
\hline Articles in scientific and technical journals & 13440757373.03 & 3 & 32235558.01 & 21 & 416.95 & .00 \\
\hline GDP per capita (ppp \$ 2005) & 1240430545.32 & 3 & 92109388.95 & 21 & 13.46 & .00 \\
\hline Third cycle education enrolment ratio (\%) & 631.01 & 3 & 196.97 & 21 & 3.20 & .04 \\
\hline OCEANIA & 14225836.30 & 3 & 734709.56 & 21 & 19.36 & .00 \\
\hline
\end{tabular}

Averages of the Final Clusters. Oceania

Table 12

\begin{tabular}{l|c|c|c|c}
\hline & Cluster 1 & Cluster 2 & Cluster 3 & Cluster 4 \\
\hline Patent applications by non-residents & 1067 & 304 & 271033 & 10301 \\
\hline Research and development spending (\% of GDP) & 2.10 & 1.53 & 2.76 & 1.76 \\
\hline Articles in scientific and technical journals & 4181 & 2491 & 208600 & 26762 \\
\hline GDP per capita (ppp \$ 2005) & 29744.61 & 73981.43 & 49853.68 & 37737.43 \\
\hline Third cycle education enrolment ratio (\%) & 73.17 & 46.15 & 94.27 & 74.56 \\
\hline OCEANIA & 81 & 40 & 6422 & 1408 \\
\hline
\end{tabular}

\section{Discussion of Results}

The results confirm the significant influence of the variable "Number of patent applications" when grouping countries based on HSI receiving economies, an influence which, as we know, occurs in combination with other innovation factors, namely the other significant variables in our study: enrolment in tertiary studies (graduate), number of publications in scientific journals, and also economic growth as measured by GDP per capita.
In this regard, after evaluating the characteristics of the sets or clusters obtained, we can conclude that in the case of the African region, two clusters, namely the third (Australia, Canada, UK, Italy, Holland and Spain) and the fourth, which includes the U.S., are characterized by both a big number of patent applications and a big number of HSI received from Africa.

Countries such as Australia, the U.S. and Canada have been implementing migration and talent attraction polices proactively for the last 30 years (Arslan et al., 2014, OECD, 
2014). In this sense programs for foreign students have proved an excellent way to attract HSI to these countries (OECD, 2014; Vandervelde \& Lommers, 2013).

In the case of European countries, in addition to the Schengen agreement, most have specific programs for HSI from other countries (Vandervelde \& Lommers, 2013, Gagliardi, 2011). Thus, Italy sets quotas for immigrants under the Nulla Osta (work permit) rules except in the case of skilled immigrants and expatriates from international companies. Holland has a specific policy for knowledge workers with a simplified immigration process. Spain has the UGE program that streamlines and simplifies the immigration process for highly skilled workers of international companies and other highly skilled personnel. The UK has the UKBA program which facilitates the recruitment by companies of highly skilled personnel. However, European countries covered by the study (except the UK) suffer from a lack of clear policies encouraging HSI. Evidence of this is shown in cluster one, which includes a large number of European countries along with others such as New Zealand and Israel. This group has very low production values in terms of patents and HSI received.

Our results show that HSI are important for an economy in the case of patent applications, since the two groups that receive the largest numbers of HSI have a higher proportion of patent production.

In the case of immigrants from Asia, it can be seen again that the countries with more proactive immigration policies are those that consequently have a larger number of patent applications by non-residents: U.S. (Cluster1), Australia, Canada and United Kingdom (Cluster 3).

A good example here would be agreements on HSI between Australia and China, or between Japan and the Philippines (OECD, 2008), which facilitate academic mobility to Australia and Japan while promoting the return of these immigrants, after their education is finalized, to their home countries so that the "brain drain" can become "brain gain" or even "circular brain".

If we talk about the results for HSI from North America, migratory flows are higher between the U.S. and Canada. This is logical since both countries maintain close cooperation on migration issues (OECD, 2014). This also happens if we talk about immigrants from Central and South America, as Canada maintains agreements with Mexico on academic mobility and temporary stay of expatriates from international companies. Also, European countries like Spain have negotiated similar agreements with countries in Central and South America as in the case of Colombia, Ecuador and the Dominican Republic.

As Hunt \& Gauthier-Loiselle (2010) have shown, skilled immigrants contribute at least twice as many patents as their native peers, which will also bring them greater benefits in the end, either because they would not have been able to commercialize their innovations in other countries, or because after arriving to the receiving country they benefited from better conditions in terms of innovation and commercialization of the patents they produced.

Also, the number of scientific publications of a particular country is relevant when grouping and redistributing the $25 \mathrm{HSI}$ receiving economies selected for this study. Furthermore, seeing the results, we can confirm that the number of HSI is greater in the two groups that show a larger number of technical and scientific publications.
Thus, the results suggest that clusters containing more productive countries in regards to scientific and technical publications are also characterized as receiving a bigger number of skilled immigrants, and, specifically those countries with policies focused on attracting international talent, especially in the case of Australia, Canada and the U.S. (OECD, 2011; Hopkins \& Levy, 2012). Our findings add to the literature of empirical evidence on the importance of scientific publications as a determining factor for HSI.

Among the aforementioned publications is, for example, the one by Stephan \& Levin (2001), which analyzed the relationship between HSI and indicators of scientific achievement in the United States.

In this regard recall that, according to the results by region, the U.S. receives twice as many Asian immigrants as immigrants of European origin, especially scientists and engineers (Rosenzweig, 2008), while Australia and Canada receive very similar numbers of HSI from Asia and Europe (almost 24,800 compared to about 23,600, respectively, in the case of Australia, and around 36,000 vs. 40,000 in the case of Canada).

Following this train of thought, the production of scientific papers should be mentioned as a predictor of HSI, which is an argument in line with the one presented regarding the number of patent applications as follows from the Kerr (2008) publication, meaning that as was established by the theory of social networks, the knowledge capital produced in the economies of receiving countries should follow the same guidelines for creation and diffusion in donor (exporters of HSI) countries through local and ethnic networks such as social or virtual networks created between collectives of HSI of similar characteristics. So, if most of the researchers who leave do not return to their countries of origin (Moed \& Halevi, 2014), to achieve a rebalancing in the intellectual and scientific capital lost in developing economies it would be necessary to implement appropriate policies, which would somehow encourage the ability to dump the capital acquired by the HSI at least partially- into ethnic and local research networks that still remain in the country of origin.

Regarding our results, despite the restrictions on visa policies in the U.S. or UK, the fact is that both countries receive a volume of HSI directly related to its scientific production. The most productive areas in terms of publications are those that are also the most attractive for highly skilled foreigners. In this sense, both the U.S. and the United Kingdom are the countries with the highest number of scientific publications in the selected sample of receiving countries, which is the object of our study, and this draws attention to the fact that the UK receives more skilled immigrants of Asian origin than skilled immigrants from Europe, despite being a European country and enjoying the advantages of the Single European Space.

On the other hand, as the OECD (2014) indicates, the number of emigrants for academic reasons in OECD countries increased by $70 \%$ over the last decade.

We can say that the rate of enrolment in postgraduate studies appears to be higher in the groups that manage to attract more HSI. In all regions that have been analyzed the cluster or group that includes the U.S. is the one which receives the highest number of HSI, while simultaneously being the group with the highest rate of enrolment in studies of this type. However, the cluster formed by Australia, Canada and UK also has a high rate 
of enrolment in line with the second HSI attraction ratio, in terms of importance.

These results add empirical evidence to analyses such as the one by Hopkins \& Levy (2012), which presented recommendations for the British government to adopt Australian or Canadian style policies on attracting skilled immigrants and foreign graduate students. According to the authors, after the United States, these two countries are centres of attraction for innovation thanks to the attractive conditions offered to scientists and doctoral students.

Although the results from our data on the rate of enrolment in postgraduate studies did not explain specifically the international flow of talent, they did show that this variable is a relevant classification criterion as it very clearly affects the distribution of recipient countries.

In this sense Dreher \& Poutvaara (2006) suggested that receiving foreign students is an effective way to attract future migration, regardless of previous immigrant population.

In the case of GDP per capita, we have the same situation as the one with the variable representing the number or rate of enrolment in third cycle studies. We can see that the group which receives the largest number of highly qualified immigrants proportionally to the size of their population is formed exclusively by the U.S., despite not having the highest GDP per capita (ranked second in the list after the group formed by Norway and Luxembourg). However, from the four existing clusters, the one with the lowest GDP per capita does have the lowest rate of HSI in proportion to the size of its population.

Thus, when GDP per capita is accompanied by other indicators, as is the case with cluster analysis, this can explain various characteristics of the recipient countries.

For example, we may note that the U.S. has unique characteristics partly due to the HSI it receives, since their presence, encouraged by a policy for attracting international talent, projects a positive impact on the variables included in our analysis acting as a virtuous circle that leads to improvements in GDP per capita. In this sense, we see how other countries with a higher per capita GDP, such as the group consisting of Norway and Luxembourg, fail to get the same benefits.

From the aforementioned point of view, the recommendations aim to increase the number and quality of universities and research centres in the donor countries, which would lead to an increase in their GDP (Beine et al., 2011).

\section{Conclusions}

Attraction of international talent are related to constituent components of innovation. Previous studies partially confirmed it for specific elements of innovation at regional level. For instance, Niebuhr (2006) found evidences in the case of patents in some regions of Germany. Gagliardi (2011) and Hopkins \& Levy (2012), respectively, found positive results in the case of the dissemination of innovation and immigrant attainment in several cities of United Kingdom. In our case, this fact is confirmed for patents, GERD, number of scientific publication and enrolment in graduate studies in an international sample of 182 sending countries and 25 receiving countries.

Similarly, and as documented by this research, HSI have become an important engine for economic growth in different countries, helping increase the number of patents, and themselves being attracted by the number of patents obtained by the receiving country. This benefits innovation in receiving countries, which means that the government should take political measures in order to remove current barriers to HSI.

On the other hand, the results obtained in all countries that have been analyzed imply that the implementation of policies enabling innovation will mean an increase in the number of HSI, so this makes it necessary to implement facilities for the further integration of the collective HSI, which will positively impact the country by helping achieve greater economic growth and productivity. In this sense, Zheng \& Ejermo (2015) reached a similar conclusion for the U.S., Canada and Australia versus Sweden.

In this regard, the strategies adopted for these countries should be designed to take greater account of the skill level of the immigrants than of their country of origin. Our data indicate that, for the United States, which the largest number of HSI, more than half of the 646,786 skilled immigrants received are of Asian origin $(338,313)$ and a fourth $(166,033)$ are from Europe. Therefore, it seems that proximity is not an incentive to skilled immigration, since the number of HSI from Central and South America in 2011 was only 77,527.

Our analysis produces cluster that combine a high rate of reception of skilled immigrants with a high production of patents, and other outcomes such as increased production of scientific papers and data on GDP per capita. This indicates that the influence between variables is of a circular type and interrelated, while also hinting that a greater number of HSI encourages an increase in the production of patents.

On a more general level this paper adds evidence to the theory of global systems, which establishes a correlation between international migration and inequality arising from economic and social damage that emigration generates to the countries of origin, not only due to the loss of highly skilled talents, but added also lost productivity.

Novel and disruptive inventions, innovation and higher productivity request time and talent (Kerr, 2010). In this sense those countries that can attract international talent will become first movers in a global and competitive market with important consequences in their level of development.

In addition, our results add empirical evidence, on the one hand to the theory of push-pull factors, because skilled migrants decide to go to countries with more favorable conditions such as the United States or other OECD nations in order to meet their demand for growth and innovation, and, secondly, it also adds evidence to network theory, since the researchers assume that receiving people fitting this profile (HSI) will attract future immigrants through the creation of local or ethnic networks, understanding this migration as a flexible and dynamic process in which novel factors such as access or membership to these social networks can modify the individual expectations held initially by the immigrants and influence the decision to stay or to return.

Also, the GDP per capita variable influences the number of HSI, especially when it coincides with any of the factors of attraction discussed before (patents, number of publications, and rate of enrolment in third cycle studies). In this regard, countries with higher levels of income per capita, such as Luxembourg and Norway, do not get the same results as, for example, the U.S., which has a lower GDP per capita but is more proactive with policies designed to attract international talent, and this helps achieve a greater number of HSI. 


\section{References}

Abdelbaki, H. (2009). Estimation of the economic impact of brain drain on the labor expelling country. The International Business \& Economics Research Journal, 8(12), 53-66.

Aldenderfer, M. S., \& Blashfield, R. K. (1984). Cluster analysis. Beverly Hills, CA: Sage. https://doi.org/10.4135/9 781412983648

Arslan, C., Dumont, J. C., Kone, Z., Moullan, Y., Ozden, C., Parsons, C., \& Xenogiagi, T. (2014). A New Profile of Migrants in the Aftermath of the Recent Economic Crisis. OECD Social, Employment and Migration. Working Papers, 160. OECD publications.

Balaz, V., Williams, A. M., \& Kollar, D. (2004). Temporary versus Permanent Youth Brain Drain: Economic Implications. International Migration, 42(4), 3-34. https://doi.org/10.1111/j.0020-7985.2004.00293.x

Bayley, K. D. (1994). Typonomies and taxonomies: An introduction to classification techniques. Thousand Oaks, Ca: Sage. https://doi.org/10.4135/9781412986397

Becker, G. S. (2009). Human Capital: A Theoretical and Empirical Analysis, with Special Reference to Education. Chicago Press.

Beine, M., Docquier F., \& Oden-Defoor, C. (2011). A Panel Data Analysis of the Brain Gain. World Development, 39(4), 523532. https://doi.org/10.1016/j.worlddev.2010.03.009

Benassy, J. P., \& Brezis, E. S. (2013). Brain drain and development traps. Journal of Development Economics, 102, 15-22. https://doi.org/10.1016/j.jdeveco.2012.11.002

Bosetti, V., Cattaneo, C., \& Verdolini, E. (2015). Migration of skilled workers and innovation: A European perspective. Journal of International Economics, 96, 311-322. https://doi.org/10.1016/j.jinteco.2015.04.002

Cekanavicius, L., \& Kasnauskiene, G. (2009). Too High or Just Right. Cost-Benefit Approach to Emigration Question. Inzinerine Ekonomika-Engineering Economics, 1(61), 28-36.

De Beer, J., Raymer, J., van der Erf, R., \& van Wissen, L. (2010). Overcoming the Problems of Inconsistent International Migration data: A New Method Applied to Flows in Europe. Journal of Population, 26(1), 459-481. https://doi.org/10.1007/s10680010-9220-Z

Dreher, A., \& Poutvaara, P. (2006). Student flows and migration. An Empirical Analysis. Institute for the Study of Labor (IZA), Working Paper $n^{\circ} 1612$.

Dumont, J. C., Martin, J. P., \& Spielvogel, G. (2007). Women on the Move: The Neglected Gender Dimension of the Brain Drain. IZA Discussion Paper, $\mathrm{n}^{\circ}$ 2920. Retrieved from http://ssrn.com/abstract=1001216.

European Commission (Eurostat) and OCDE (2005). Guidelines for collecting and interpreting innovation data. Oslo Manual. Eurostat \& OCDE ( $3^{\mathrm{a}} \mathrm{Ed}$.).

Everitt, B. S. (1993). Cluster Analysis. London: Edward Arnold.

Fan, P. (2011). Innovation capacity and economic development: China and India. Economic Change Restructure, 44, 49-73. https://doi.org/10.1007/s10644-010-9088-2

Gagliardi, L. (2011). Does Skilled Migration Foster Innovative Performance? Evidence from British Local Areas. Papers in Regional Science, 97, 773-794.

Garcia-Rodriguez, Y., Mihi-Ramirez, A., \& Navarro-Pabsdorf, M. (2015). Highly-Skilled Migration, Migrant Networks and the Prestige of Academic Institutions. Inzinerine Ekonomika-Engineering Economics, 26(5), 500-506. https://doi.org/10.5755/j01.ee.26.5.12463

Gungor, N. D., \& Tansel, A. (2007). Brain drain from Turkey: The case of professionals abroad. International Journal of Manpower, 29(4), 323-347. https://doi.org/10.1108/01437720810884746

Hopkins, L., \& Levy, C. (2012). Simply the Best? Highly-skilled migrants and the UK's knowledge economy. Working Paper the Work Foundation. Retrieved from http://www.theworkfoundation.com/downloadpublication/report/315_simply\% 20the\%20best\%20twf\%20format.pdf.

Hunt, J., \& Gauthier-Loiselle, M. (2010). How does immigration boost innovation? American Economic Journal: Macroeconomics, 2(2), 31-56. https://doi.org/10.1257/mac.2.2.31

Hussain, S. M. (2015). Reversing the Brain Drain: Is it Beneficial? World Development. 67, $310-322$. https://doi.org/10.1016/j.worlddev.2014.10.023

Jaffe, A. B., \& Trajtienberg, M. (2002). Patents, Citations \& Innovations: A Window on the Knowledge Economy. Cambridge, MA: MIT Press.

Jaffe, A. B., Trajtienberg, M., \& Henderson, R. (1993). Geographic localisation of knowledge spillovers as evidenced by patent citations. Quarterly Journal of Economics, 108, 577-598. https://doi.org/10.2307/2118401 
Jajri, I., \& Ismail, R. (2014). Determinants of migration from ASEAN-3 into Malaysia. Asian-Pacific Economic Literature, 28 (2), 52-62. https://doi.org/10.1111/apel.12072

Kerr, W. (2008). Ethnic scientific communities and international technology diffusion. The Review of Economics and Statistics, 90, 518-537. https://doi.org/10.1162/rest.90.3.518

Kerr, W. J. (2010). Breakthrough inventions and migrating clusters of innovation. Journal of Urban Economics, 67, 46-60. https://doi.org/10.1016/j.jue.2009.09.006

Krisciunas, S. K., \& Greblikaite. J., (2007). Entrepreneurship in Sustainable Development: SMEs Innovativeness in Lithuania. Inzinerine Ekonomika-Engineering Economics, 4(54), 20-26.

Love, J. H., \& Roper, S. (1999). The Determinants of Innovation: R\&D, Technology Transfer and Networking Effects. Review of Industrial Organization, 15(1), 43-64. https://doi.org/10.1023/A:1007757110963

Masuduzzaman, M. (2014). Workers' Remittance Inflow, Financial Development and Economic Growth: A Study on Bangladesh. International Journal of Economics and Finance, 6(8), 247-267. https://doi.org/10.5539/ijef.v6n8p247

Metelski, D., \& Mihi-Ramirez, A. (2015). The Economic Impact of Remittances and Foreign Trade on Migration. GrangerCausality approach. Inzinerine, Ekonomika-Engineering Economics, 26(4), 364-372.

Mihi-Ramirez, A., Garcia-Rodriguez, Y., \& Cuenca-Garcia, E. (2016). Innovation and international high skilled migration. Inzinerine Ekonomika-Engineering Economics, 27(4), 452-461. https://doi.org/10.5755/j01.ee.27.4.14396

Moed, H. F., \& Halevi, G. (2014). The Multidimensional Assessment of Scholarly Research Impact. Journal of the Association for Information Science and Technology, 66(10), 1988-2002. https://doi.org/10.1002/asi.23314

Naghavi, A., \& Strozzi, C. (2015). Intellectual property rights, Diasporas, and domestic innovation. Journal of International Economics, 96, 150-161. https://doi.org/10.1016/j.jinteco.2015.01.007

Nguyen, L. D., Raabe. K., \& Grote, U. (2015). Rural-Urban Migration, Household Vulnerability and Welfare in Vietnam. World Development, 71, 79-93. https://doi.org/10.1016/j.worlddev.2013.11.002

Niebuhr, A. (2006). Migration and innovation: does cultural diversity matter for regional R\&D activity? IAB Discussion Paper, $\mathrm{n}^{\circ}$ 14.

OECD (2009). OECD Territorial Reviews: Toronto, Canada. OECD Publications.

OECD (2011). OECD Database on Immigrants in OECD and non-OECD Countries. OECD Publishing. Retrieved from http://www.oecd.org/els/ mig/oecdmigrationdatabases.htm.

OECD (2014). International Migration Outlook 2014, Paris: OECD Publishing.

OECD (2015). OECD Science, Technology and Industry Scoreboard 2015: Innovation for growth and society, OECD Publishing, Paris.

Portes, A., \& Walton, J. (1981). Labor, class and the international system. Academic Press, New York.

Rosenzweig, C., Karoly, D., Vicarelli, M., Neofotis, P., Wu, Q., Casassa, G., \& Tryjanowski, P. (2008). Attributing physical and biological impacts to anthropogenic climate change. Nature, 453(7193), 353-357. https://doi.org/10.1 038/nature06937

Sara, T. S., Jackson, F. H. \& Upchurch, L. T. (2012). Role of Innovation in Hi-Tech-Exports of a Nation. International Journal of Business and Management, 7(7), 85-93. https://doi.org/10.5539/ijbm.v7n7p85

Schumpeter, J. A. (1934). The Theory of Economic Development. Cambridge, MA, Harvard University Press.

Stephan, P. E., \& Levin, S. G. (2001). Exceptional contribution to US science by the foreign-born and foreign-educated. Population Research and Policy Review, 20, 59-79. https://doi.org/10.1023/A:1010682017950

Stuen, E. T., Mobarak, A. M., \& Maskus, K. E. (2007). Foreign PhD Students and Knowledge Creation at U.S. Universities: Evidence from Enrollment Fluctuations. University of Colorado, Working paper.

UNESCO (2009). Annual Report. United Nations Educational, Scientific and Cultural Organization. Retrieved from http://unesdoc.unesco.org/images/0018/001849/184967s.pdf.

Vandervelde, E., \& Lommers, M. (2013). Comparative Immigration study 2013-2014. Deloitte Network: United Kingdom.

Vidal, J. P. (1998). The effect of emigration on human capital formation. Journal of Population Economics, 11(4), 589-600. https://doi.org/10.1007/s001480050086

World Economic Forum. (2014). The Global Competitiveness Report 2014-2015. Geneva.

Zheng, Y., \& Ejermo, O. (2015). How do the foreign-born perform in inventive activity? Evidence from Sweden. Journal of Population Economics, 28 (3), 659-695. https://doi.org/10.1007/s00148-015-0551-2

The article has been reviewed.

Received in January, 2017; accepted in April, 2017. 
Copyright of Engineering Economics is the property of Engineering Economics and its content may not be copied or emailed to multiple sites or posted to a listserv without the copyright holder's express written permission. However, users may print, download, or email articles for individual use. 